\title{
Student's Attitude towards Peer-to-Peer Music File Sharing and Downloading from Internet-A Cross Sectional Study of American and Moroccan Students
}

\author{
Talha Harcar \\ Pennsylvania State University \\ Pennsylvania, USA \\ Abdul Naveed Tariq \\ Seneca College of Applied Arts and Technology \\ Toronto, Canada
}

\begin{abstract}
Purpose: The main aim of this study is to compare two different cultures in terms of ethical and legal use of music sharing technology. Students' perceptions of downloading from web and sharing music with each other varies across cultures. Such practices have caused significant losses to music and film industry.

Methodology/Sampling: Primary data was collected from Morocco and US university students on a pretested questionnaire. Besides frequency distributions, chi-square, t-test and confirmatory factor analysis were used as inferential tools.

Findings: Results showed a considerable difference in between Moroccan and American students' attitude in terms of music files sharing and downloading. Compare to Moroccans, American students were more aware of ethical, and legal aspects of music file sharing and download from web.

Practical Implications: Research findings suggests music industry should focus on making music products more affordable and create awareness towards music piracy through promotional campaigns keeping in mind the cultural differences of end users. The research findings will set a platform for further comparative studies in the same context.
\end{abstract}

Keywords: File Sharing, Piracy, Free downloads, Cross-Culture.

JEL Classification: O200.

* The material presented by the authors does not necessarily portray the viewpoint of the editors and the management of the Institute of Business \& Technology (IBT).

* Talha Harcar; tdh13@psu.edu

* Abdul Naveed Tariq: abdul.tariq@senecacollege.ca

C JMSS is published by the Institute of Business and Technology (IBT). Main Ibrahim Hydri Road, Korangi Creek, Karachi-75190, Pakistan. 


\section{INTRODUCTION}

The free downloading of music and file sharing is an issue that is currently being examined by numerous researchers. A number of papers have been published on how free downloading has impacted revenues in the music industry. This active software piracy impacts the broader economy as well as the entertainment industry (copyright holders, music distributors, movie makers and distributors, artists, and all business related to the downloading intellectual property from the Internet). Obviously, this can be very costly for firms engaging in intellectual property transactions. Revenue losses due to unethical and illegal downloading have been estimated around $\$ 200$ billion per year and it was found in general there is a significance increase in this trend. (Michael Ba, 2013). According to BSA (2012), more than half of world computer users pirate software. If intellectual piracy could be prevented, with firms capable of making their materials not freely accessible, these businesses would certainly turn more profitable.

Some countries have recently outlawed free downloading of intellectual property over the Internet. For example, since 2006, France has outlawed peer-to- peer file sharing. France started out with prohibiting the copying of shared files. Now the French government has outlawed the sharing of any data file on the Internet. This act reduces the amount of illegal software piracy and commerce. According to the French statistics, one billion movies and songs were illegally downloaded in 2006, thereby reducing total revenue for these industries by approximately 50\% (Audrey, 2007).In addition, nearly 9 million French people participate in downloading files from the Internet, while only $15 \%$ of this number is said to be legal downloads (Dimeglio, 2007). France takes copyright and infringement issues very seriously asthese have an enormous impact on business ethics and economics.

Sanctions are becoming more severe for peer-to-peer file sharing. For example, in Minnesota, a count fined a housewife for a sanction of 9,250 dollars for each illegal music download, although the housewife simply downloaded music using peer-to-peer technology and shared this music with others on the internet (Altermedia France, 2007).

\section{MUSIC INDUSTRY and PIRACY}

According to the International Anti-Counterfeiting Coalition(IACC, 2005), only 5 percent of all products are estimated to be counterfeit worldwide. In the United States, the cost of counterfeiting is estimated to be $\$ 200$ billion per year (Chaudhry, Cordell and Zimmerman, 2005). The music industry is one of these industries most highly affected by intellectual piracy. Between 1979-1984 music sales were trending downward. With the emergence of compact disk technology in the second half of the 1980s, recorded music sales picked up and reached nearly four billion dollars (Pikas et al., 2011). Since 2000 CDs have become popular and the market share of cassette tapes and vinyl LPs has declined nearly 40 percent(Krasilovsky et al., 2007). Although downloading of music has caught on over the last ten years,CDs with characteristic sales continue to be the market leader in the music industry. However, CD music sales are on the decline while music downloading on websites such as iTunes is increasing in popularity and market share. With the emergence of online music downloads as the new distribution technology, CD sales declined $20 \%$ to 361 million units from 2007 to 2008 . The market share of CD sales in the music industry declined from $90 \%$ in 2008 to $84 \%$ in 2009 (Stone, 2009).

IBT Journal of Business Studies (Formerly Journal of Management \& Social Sciences) 
Peer-to-peer (P2P) network architectures facilitate resource sharing directly among independent individual network users (henceforth known as peers). Currently, these resources are mainly files containing digitized information content such as music, movies, pictures, software, or text (Asvanund et al., 2004). Peer behaviors control resource availability and consumption patterns. Therefore, the more the people downloading files, the faster and more efficient the process becomes. Thus, P2P networking is different than the traditional clientserver architecture, where all network resources are contained in and managed by a central server (Parameswaran et al., 2001). Since the inception of P2P technology, the unique characteristic of this software has made it a more preferable instrument of data exchange in a network than client server architecture. The biggest problem with this new technology is copyright infringement which can bring about serious financial losses to the music and entertainment industries.

\section{LITERATURE REVIEW}

Research has shown music file sharing can cause drop in sales from 5 to $7.6 \%$ (Michel, 2004; Hong, 2004). Zentner (2003) found that P2P music file sharing entails a probability of drop in music purchase by $30 \%$ on average. Liebowitz (2004) tried to investigate the factors other than file sharing behind the fall in music sales but concluded alternative factors were not significant in drop of music sales. Besides, Blackburn (2004) found free download as the most probable vital source of drop in music sales.

Soft lifting - copying movies or music files - is an impersonal act, and people cannot relate such behavior to directly harming someone. As such, in many cases, respondents considered this socially acceptable and ethical (Vitell 2003; Vitell and Muncy, 1992). Anonymity of computer user may be another reason why music continues to be shared with no realization about the impact of copyrights violation (Chiou et al., 2005). Interestingly, the studies made by Moores and Chang (2006) showed that respondents, while considering software piracy as a violation of intellectual property rights, nonetheless maintained that they were not doing anything wrong.

Lau (2006) proposed that the price/cost of original software worked asa compelling trigger for software piracy. In his research the excessive price of the original software was found to be the key factor pushing consumers to commit piracy. Bhattacharjee et al., (2003) found that, though there is a difference in quality between original music files and copied compressed files, consumers don't consider this quality difference significant. It has also been observed that music piracy significantly exceeds soft lifting. The reason is the smaller size of music files compared to that of software. Consumers can enjoy their copied music files instantaneously while in case of software they need to make an extra effort to learn those softwares. However, Gopal et al., (2004) consideredthe same ethical considerations for soft lifting as for music piracy. Many consumers of pirated CDs blame music companies for charging very high prices and are comfortable in copying or buying pirated music CDs. Kwong and Lee (2002) also pointed out that copyright owners charge premium prices that is the main cause of Internet music piracy. Social influence, individual's personality, pricing and the economic prosperity level of countries were found to be related with consumers' perception of purchasing pirated software products (Sabbir, Ahasanul, \& Mahbubur, 2011).

According to an empirical study involving people aged between 11 and 24, 36\% of the survey respondents who are middle-class university students agree or strongly agree that they 
obtain their music mostly through the purchase of CDs, $21.34 \%$ of the respondents agree or strongly agree that they obtain their music through paid downloads, and $78.66 \%$ of the respondents agree or strongly agree that they obtain their music via unpaid downloads. Of the respondents, $62.67 \%$ disagreed or strongly disagreed that they would pay for something they could have for free, and $68 \%$ agreed that they would be more willing to listen to new music if all downloads were free; and 56\% stated that they download their music mostly through iTunes, the Apple online music store. The survey data concluded that the respondents downloaded an average of about 85 songs per month, mostly on illegal or file sharing systems (Pikas et al., 2011).

File sharing of $\mathrm{P} 2 \mathrm{P}$ music can be contrasted with buying of pirated products. The copying of music files by consumers, either from internet or from friends,seems to carry animplicit justification thatonce an original CD after liking is purchased and subsequently set to go viral on free download as demonstrable in behavior patterns of consumers sampled (Bhattacharjee et al., 2003; Ki et al., 2006;Peitz and Waelbroeck, 2006; Spitz and Hunter, 2003). In other words, people who are willing to buy the original music may also get attracted in $\mathrm{P} 2 \mathrm{P}$ music sharing to listen to the music first and then to make a purchase.

Friends, classmates, teachers, online forums, or newspapers and magazines are the driving factors which influence and encourage P2P file sharing (Chiu \& Chou, 2011). There are many different types of $\mathrm{P} 2 \mathrm{P}$ file sharing software. Owing to easy availability of different product features, most users utilize more than one type of $\mathrm{P} 2 \mathrm{P}$ file-sharing software. The value proposition of this technology is that it enables users to save money and time, access all types of music, and obtain files that were previously unreachable (Chiu \& Chou, 2011).

In $\mathrm{P} 2 \mathrm{P}$ music sharing community, individuals might not consider themselves a counterfeiting party making commercial gains but a contributor in a mutually beneficial social group. Success of P2P networks lies in users' readiness to share files. As in social exchange theory, reciprocity is a prerequisite in $\mathrm{P} 2 \mathrm{P}$ network functionality that removes the guilt of freerider phenomenon (Blau, 1964). Ang et al., (2001) pointed out that some people see entertainers as professionals who enjoy lavish life, conveniently oblivious of music piracy and, by derived association, feel less guilt in so doing. In P2P networking, individuals share their valuable resources with the expectations that others will also follow suit (Tiwana and Bush, 2000).

However, the other school of thought defends P2P sharing of music files. Freeware theory remains popular among the many internet users. According to them, digital information should be free and in essence can be beneficial for the whole society. Consumers should be facilitated in music purchase by allowing them to listen to songs and choose the songs package they like rather an unwanted song bundle made by copyright owner. Stallman (1995) advocates freeware policy and considers copyright enforcement in information age deleterious to a society. The success and expansion of open sources business model companies'shores up ground for adoption of open source software to maximize the social benefits of information age.

\subsection{Research objectives}

The main objective of this research is to compare two different cultures in context of the ethical use of technology. More specifically, the goals of this research are to:

1. Analyze the frequency of downloading free music from internet among university students 
2. Measure the students' awareness level of the ethics of downloading music

3. Examine the different perceptions of ethical and unethical use of technology

4. Evaluate the difference between two cultures for downloading and copying music

\section{METHODOLGY}

\subsection{Questionnaire Design}

A questionnaire was administered to assess respondents' perceptions to ethical behaviors for downloading files on the internet. The questionnaire consisted of four groups of questions:

- Screening questions used to categorize the respondents into two categories: Internet usage and frequency of downloading free music on the internet.

- Preferences between legal and illegal copies of music.

- Attitudes towards and perceptions about downloading and copying free music on the Internet.

- Demographic characteristics of students including gender and age group.

Students' attitudes toward peer-to-peer music file sharing and downloading music on the internet were measured by 5-scale Likert type items. The questionnaire items are related to downloading illegal music from internet and copying music files for friends. There were items related to perception on downloading music from the Internet, items focusing on the behavior of respondents toward downloading free music or sharing music files with friends.

The original form of the questionnaire was developed in English and later translated into Arabic by the authors with expert assistance in translation. The order of items was presented randomly; items were not grouped together with other items having a similar character. The questionnaire consisted of 12 items that were rated by the participants from 1 (strongly disagree) to 5 (strongly agree). Reviewers were asked whether the items were relevant to the aim of the study. Revisions were based on their comments and suggestions.

In order to validate the development of this questionnaire in both cultures a pilot questionnaire was administered to 10 respondents in both Morocco and United States. The main purpose of the pilot questionnaire was to ensure a common understanding of the questionnaire items in both cultures. Results of the pilot questionnaire revealed that the illegal download concept was unclear to Moroccan respondents. A clarification was made to better explain the concept of illegal downloading. The questionnaire created throughout an iterative process of statement generation, current internet marketing, and international consumer behavior literature.

\subsection{Data Collection and Sample}

The data for this study was collected through self-administered questionnaires. The questionnaires were administered in two different locations. They were administrated first in Al-Akhawayn University, Ifrane, Morocco, and then in the Pennsylvania State University, Beaver Campus, USA. 
AlAkhawayn University was founded in 1993 by Royal Dahir (charter), and Al Akhawayn University in Ifrane (AUI) opened in January 1995. The student population is around 1300 students with approximately $50 \%$ males and $50 \%$ females. Students, staff, and faculty members are multicultural, belonging to over 25 different nationalities. The majority of the students is full time and lives on campus. In addition, many of these students come from some of the affluent families in Morocco. The resort town of Ifrane, where the university is located, has a regular population of 12,000 that expands to nearly 100,000 on weekends, holidays, and summers (Fast Facts about AUI, 2014).

On the other hand, The Pennsylvania State University is one of the largest university systems in the United States. Penn State Beaver is located in a comfortable suburban neighborhood within easy access to Pittsburgh, PA. Like all Penn State campuses, Beaver offers the first two years of most of Penn State's 160 baccalaureate degrees. In addition, six bachelor's degrees and four associate's degrees can be obtained. Most of the approximately 800 students are first-generation college students from working class families (Penn State Beaver, 2014). In both universities students were informed that participation was completely voluntary and that their responses would be reported only at the aggregate level and would be kept anonymous.

A total of 100 Moroccan and 116 American students attending two different universities participated in the study. The participants were majoring in different areas. The ages of the participants were between 17 and 30 years $(\mu=21.15$; SD $=1.55)$. The sample size of the Moroccan sample was created by 59 males and 41. The sample size of USA was created by 69 males and 47 females. Put in other words, the sample consisted of about $40.7 \%$ male and $59.3 \%$ female students. Moroccan female students are $46.1 \%$ of the total female sample while $46.6 \%$ of male respondents are Moroccan. The ratios for American students related to gender are $53.9 \%$ female versus $53.4 \%$ of males. About $39.1 \%$ of students 19 years and younger were Moroccan, while about $62.1 \%$ of those 24 years and older were American. The group falling in the age bracket of 20-23 years has the highest ratio (75.9) for overall sample. More specifically $80.0 \%$ of the Moroccan students belong to this category. This is ratio is $72.4 \%$ for Americans. There were 63 freshmen, 68 sophomores, 52 junior and the rest (33) created seniors.

\section{RESEARCH FINDINGS}

\subsection{Internet Usage Habits of the Respondents}

In addition to demographic characteristics of students and information related to internet usage, connection time and downloading habits as of frequency of music download were also investigated. There were statistically significant differences between Moroccan and American students in terms of time connected to the Internet and frequency of downloading music on the Internet. Three percent of Moroccan students use the Internet less than one hour per day, while the ratios are $9.0 \%$ for $1-2$ hours of usage, $22.0 \%$ for $2-3$ hours, $14 \%$ for $3-4$ hours and $52 \%$ for more than 4 hours of daily use. Similar ratios for American students were found to be 2.6, $7.8,40.5,24.1$ and $25 \%$, respectively. Chi-Square results support the existence of significant differences between the Moroccan and American students on Internet connect time. 
Student's Attitude towards Peer-to-Peer Music File Sharing and Downloading from Internet-A Cross Sectional Study of American and Moroccan Students

Table 1

Respondent Demographic Characteristics and Internet Usage Habits

\begin{tabular}{|c|c|c|c|c|}
\hline & $\begin{array}{l}\text { Moroccan } \\
(100)\end{array}$ & $\begin{array}{l}\text { American } \\
(116)\end{array}$ & Total & Chi Square \\
\hline Gender & & & & NS \\
\hline Male & $59.0 \%$ & $59.5 \%$ & $59.3 \%$ & \\
\hline Female & $41.0 \%$ & $40.5 \%$ & $40.7 \%$ & \\
\hline Age Group & & & & NS \\
\hline Under 20 & $9.0 \%$ & $12.1 \%$ & $10.6 \%$ & \\
\hline $20-23$ & $80.0 \%$ & $72.4 \%$ & $75.9 \%$ & \\
\hline 24 and over & $11.0 \%$ & $15.5 \%$ & $13.4 \%$ & \\
\hline Daily use of Internet & & & & $19.17(*)$ \\
\hline Less than an hour & $3.0 \%$ & $2.6 \%$ & $2.8 \%$ & \\
\hline $1-2$ hours & $9.0 \%$ & $7.8 \%$ & $8.3 \%$ & \\
\hline $2-3$ hours & $14.0 \%$ & $40.5 \%$ & $31.9 \%$ & \\
\hline 3-4 hours & $22.0 \%$ & $24.1 \%$ & $14.9 \%$ & \\
\hline More than 4 hours & $52.0 \%$ & $25.0 \%$ & $37.5 \%$ & \\
\hline $\begin{array}{l}\text { Frequency of Downloading } \\
\text { Music }\end{array}$ & & & & $12.67(* *)$ \\
\hline Daily & $11.0 \%$ & $3.4 \%$ & $6.9 \%$ & \\
\hline $2 / 3$ times a week & $7.0 \%$ & $4.3 \%$ & $5.6 \%$ & \\
\hline Once a week & $13.0 \%$ & $6.9 \%$ & $9.7 \%$ & \\
\hline Less than once a week & $15.0 \%$ & $12.9 \%$ & $13.9 \%$ & \\
\hline Once a month & $15.0 \%$ & $27.6 \%$ & $21.8 \%$ & \\
\hline Less than once a month & $30.0 \%$ & $30.2 \%$ & $30.1 \%$ & \\
\hline Never & $9.0 \%$ & $14.7 \%$ & $12.0 \%$ & \\
\hline
\end{tabular}

$\mathrm{NS}=$ not significant, $(*)$ significant relationship for 0.01 significance level

$(* *)$ significant relationship for 0.05 significance level

As regards downloading music from the internet, $31.0 \%$ of Moroccan students downloaded music at least once a week, whereas $25.9 \%$ of American students downloaded music during the same time frame. All other downloading frequencies distributed between Moroccan and American students can be found on Table 1. Chi-Square results indicated significant differences between Moroccan and American students for the frequency of downloading music through the Internet. The Chi Square test value was found 12.67 which signifies less than 0.01 of $p$ value. 


\subsection{Attitudes toward Downloading Free Music on the Internet}

Most of the respondents believe that the majority of students prefer free downloading music rather than legally copying music files or CDs from their friends. Another question was designed to askparticipants if they would primarily buy music legally. 24.3\% of Moroccan students indicated "yes" while the ratio was $75.7 \%$ for American students. Statistics, relating in addition to the different attitudes toward free music downloading or copying,were analyzed by using Chi-Square test covering both Moroccans and Americans. The results indicate that there are statistically significant differences among two different student groups by their attitudes toward free music downloading or copying.

To understand the differences and similarities between US and Moroccan students' attitude toward downloading free music, statistical tests were performed on respondents' reactions to thirty-six statements related to the research model. Table 2 shows that there are several statistically significant differences between US and Moroccan students at $\mathrm{p} \leq 0.01$ level. Results from the study indicate that there are discernible attitudinal and behavioral differences between American and Moroccan students. The major differences between the two groups of respondents from the two countries are shown below:

- American students are more convinced that it is illegal to download music from internet.

- Compared to American students, Moroccan students are more of the opinion that it is ethical to download free music from internet.

- More so than their American counterparts, Moroccan students believe that buying and selling of pirated music CDs is OK.

- Moroccan respondents are more inclined to the view that the majority of students copy music files or CDs from their friends.

- In general more of Moroccan students think that "majority of students copy music files or CDs from their friends" than American students.

- Compared to American respondents, Moroccan respondents are more likely to download free music from internet.

- Moroccans more than Americans copy music CD's from their friend.

- More Americans than Moroccans believe majority of students buy original music CD's.

- More Americans than Moroccans have bought their own music in legal ways. 
Student's Attitude towards Peer-to-Peer Music File Sharing and Downloading from Internet-A Cross Sectional Study of American and Moroccan Students

Table 2

Differences and Similarities between Moroccan and American Students' Attitude toward Downloading Music on the Internet

\begin{tabular}{|c|c|c|c|c|}
\hline Attitude Statements & $\begin{array}{l}\text { Mean } \\
\text { Moroccan }\end{array}$ & $\begin{array}{l}\text { Mean } \\
\text { USA }\end{array}$ & t-value & Sig.* \\
\hline $\begin{array}{l}\text { 1. It is illegal to download music from internet. } \\
(*)\end{array}$ & 2.79 & 3.23 & -2.502 & 0.011 \\
\hline $\begin{array}{l}\text { 2. It is ethical to download free music from } \\
\text { internet. }(*)\end{array}$ & 3.07 & 2.74 & 2.901 & 0.004 \\
\hline $\begin{array}{l}\text { 3. Payments always should be made when you } \\
\text { download music. }\end{array}$ & 2.76 & 2.71 & -0.381 & 0.703 \\
\hline $\begin{array}{l}\text { 4. Music bought once is unethical to copy or } \\
\text { share. }\left({ }^{*}\right)\end{array}$ & 2.35 & 2.87 & -4.852 & 0.000 \\
\hline $\begin{array}{l}\text { 5. Buying and selling of pirated music CDs is } \\
\text { OK. }\left({ }^{*}\right)\end{array}$ & 2.14 & 1.85 & -2.279 & 0.008 \\
\hline $\begin{array}{l}\text { 6. Majority of students download by P2P music } \\
\text { sharing technology. }\end{array}$ & 3.58 & 3.49 & 0.730 & 0.464 \\
\hline $\begin{array}{l}\text { 7. Majority of students copy music files or CDs } \\
\text { from their friends. }(*)\end{array}$ & 4.02 & 3.67 & 2.378 & 0.018 \\
\hline $\begin{array}{l}\text { 8. Majority of students prefer free download } \\
\text { music than legal copies }\end{array}$ & 4.25 & 4.14 & 1.204 & 0.940 \\
\hline $\begin{array}{l}\text { 9. Mostly I download free music from Internet. } \\
(*)\end{array}$ & 2.21 & 1.90 & 2.821 & $0.005^{*}$ \\
\hline $\begin{array}{l}\text { 10. Mostly I copy music CD's from my friends. } \\
(*)\end{array}$ & 3.21 & 2.87 & 2.673 & $0.008^{*}$ \\
\hline $\begin{array}{l}\text { 11. Majority of students buy original music CDs } \\
(*)\end{array}$ & 1.93 & 2.25 & -2.914 & $0.004 *$ \\
\hline 12. Mostly I buy my own music in legal ways $(*)$ & 2.90 & 2.36 & -4.579 & $0.000^{*}$ \\
\hline
\end{tabular}

(*) Significant at $\propto<=0.01$

In order to assess the validity of the scale items, a factor analysis was performed upon responses to the perceived attitudes towards downloading free music and copying from friends. The results of the exploratory factor analysis are reported in Table 3. The analysis yields two factors (eigenvalues of 4.2 and 2.4, respectively) consisting of twelve items of the scale. With Cronbach alphas of 0.857 and 0.726 for Americans and 0.822 and 0.707 for Moroccans, these factors seem to provide a means of describing the differences in perceptions of downloading music from internet in a legitimately dependable manner. While further scale refinement is suggested by the component loadings and small percentage of variance explained, these initial factors propose labels of "Morality" and "Practice." The first factor appears to include matters of illegal downloading, ethical problems, payments, buying and selling pirated music, copying or sharing music; the second factor consists of items that relate to the practice of downloading free music, copying music files, buying original music, and buying music in legal ways. Correlation between "Morality" and "Practice" factor was found pretty low (0.678), which indicatesincongruity between what students believe to be moral and ethical and what they do in practice. 
Table 3

Confirmatory Factor Analysis for American and Moroccan Students

\begin{tabular}{|c|c|c|c|c|c|c|}
\hline & \multicolumn{2}{|c|}{ Factor loadings } & \multicolumn{2}{|c|}{ \%variance explained } & \multicolumn{2}{|c|}{ Cronbach alpha } \\
\hline & USA & Morocco & USA & Morocco & USA & Morocco \\
\hline Morality & & & 8.721 & 7.978 & 0.857 & 0.822 \\
\hline $\begin{array}{l}\text { It is illegal to download music from } \\
\text { internet. }\end{array}$ & 0.814 & 0.787 & & & & \\
\hline $\begin{array}{l}\text { It is ethical to download free music from } \\
\text { internet. (R) }\end{array}$ & 0.685 & 0.615 & & & & \\
\hline $\begin{array}{l}\text { Payments always should be made when } \\
\text { you download music. }\end{array}$ & 0.669 & 0.605 & & & & \\
\hline $\begin{array}{l}\text { Music bought once is unethical to copy or } \\
\text { share. }\end{array}$ & 0.604 & 0.618 & & & & \\
\hline $\begin{array}{l}\text { Buying and selling of pirated music CDs } \\
\text { is OK. }\end{array}$ & 0.697 & 0.738 & & & & \\
\hline Practice & & & 13.875 & 13.602 & 0.726 & 0.707 \\
\hline $\begin{array}{l}\text { Majority of students download by } \mathrm{P} 2 \mathrm{P} \\
\text { music sharing technology. }\end{array}$ & 0.811 & 0.779 & & & & \\
\hline $\begin{array}{l}\text { Majority of students prefer free download } \\
\text { music than legal copies. }\end{array}$ & 0.679 & 0.653 & & & & \\
\hline $\begin{array}{l}\text { Majority of students copy music files or } \\
\text { CDs from their friends }\end{array}$ & 0.639 & 0.672 & & & & \\
\hline $\begin{array}{l}\text { Mostly I download free music from } \\
\text { Internet. }\end{array}$ & 0.733 & 0.691 & & & & \\
\hline $\begin{array}{l}\text { Majority of students buy original music } \\
\text { CDs }\end{array}$ & 0.619 & 0.659 & & & & \\
\hline $\begin{array}{l}\text { I am interested in information about my } \\
\text { dental health. }\end{array}$ & 0.581 & 0.621 & & & & \\
\hline $\begin{array}{l}\text { Mostly I copy music CD's from my } \\
\text { friends. }\end{array}$ & 0.725 & 0.736 & & & & \\
\hline Mostly I buy my own music in legal ways & 0.725 & 0.736 & & & & \\
\hline
\end{tabular}

(R) Indicates reverse coding

These twelve statements are then applied in the remainder of the analysis of segment differences in response from different countries.

Responses to the perceived frequency of occurrence of music downloading and sharing practices and beliefs of unethical and legal behaviors are employed to cluster respondents with the results shown in Table 4.

Both countries' students were clustered using the nearest neighbor method with a squared Euclidean distance measure. As it can be followed in Table 4, two distinct groups of students arise from the cluster analysis. Respondents in Cluster One have significantly higher moral and ethical values for each attitude statements than do those in Cluster Two. Observation of students' country of origin for these two clusters makes it clear to suggest that the students with higher moral and ethical values (those in Cluster One who perceive downloading free music illegal and unethical) are Americans. Female students tend to predominate in Cluster One, maintaining the belief that downloading and copying music file for free is not ethical and illegal. On the other hand, men tend to fall more often in the cynical, Cluster Two, group. Thus, 
Student's Attitude towards Peer-to-Peer Music File Sharing and Downloading from Internet-A Cross Sectional Study of American and Moroccan Students

there do appear to be some differences in demographic segments concerning perceptions of downloading and copying free music.

Table 4

Cluster Analysis of Moroccan and American Students' Attitude toward Downloading Music on the Internet

\begin{tabular}{|l|l|l|}
\hline & Cluster I & Cluster II \\
\hline It is illegal to download music from internet. & 3.28 & 2.79 \\
\hline It is ethical to download free music from internet. (R) & 3.23 & 2.34 \\
\hline Payments always should be made when you download music. & 2.69 & 2.13 \\
\hline Music bought once is unethical to copy or share. & 2.98 & 2.34 \\
\hline Buying and selling of pirated music CDs is OK. (R) & 2.20 & 1.79 \\
\hline Majority of students download by P2P music sharing technology. & 3.76 & 3.02 \\
\hline Majority of students prefer free download music than legal copies. & 4.35 & 3.89 \\
\hline Majority of students copy music files or CDs from their friends & 4.23 & 3.98 \\
\hline Mostly I download free music from Internet. (R) & 2.34 & $2 . .69$ \\
\hline Majority of students buy original music CDs & 1.98 & 2.32 \\
\hline Mostly I copy music CD's from my friends. (R) & 3.25 & 2.98 \\
\hline Mostly I buy my own music in legal ways & 2.87 & 2.36 \\
\hline
\end{tabular}

\section{DISCUSSIONS AND MANAGERIAL IMPLICATIONS}

The results of this research indicate that there are considerable differences among Moroccan and American university students. Most of the Moroccan students believed that their music file downloading behavior was not illegal and unethical, while American students felt it was illegal and unethical. As regards students who did download copyright restricted music files, knowing well it was illegal, we can surmise that their behavior was due primarily to lack of discretionary income. Consequently, the high market price of music files could be one reason that students illegally downloaded files even though they felt it was considered unethical behavior. The outcome of this research affords a comprehensive, integrated framework for policy makers and business enterprises to understand the dynamic relationships among different cultures in an attempt to draw consumers' perceptions towards purchasing pirated music products. It is recommended that managers and music producers in general should recognize the cultural and economic factors that may be implicated in the usage of illegal music. Further research is necessary to examine the relationship between product pricing and purchasing products illegally over the Internet.

\section{REFERENCES}

Altermedia, F. (2007). Amende record pour telechargement illegal de music, Altermadia France, accessed April 25, 2014,http://fr.altermedia.info/general/amende-record-pourtelechargement-illegal-de-musique_11666.html.

Ang, S. H., Cheng, P. S., Lim E. A. C. and Tambyah, S. K. (2001). Spot the Difference: Consumer Responses towards Counterfeit, Journal of Consumer Marketing, 18(3), pp. 219235. 
Asvanund, A., Clay, K., Ramayya, K., Smith, M. D. (2004). An Empirical Analysis of Network Externalities in Peer-to-Peer Music-Sharing Networks, Information Systems Research, 15 (2), pp. 155-174.

Audrey,C. (2007). France: Le telechargement illegal sur le grill? Generation Nouvelles Technologies, GNT, accessed April 25, 2014,http://www.generation-nt.com/telechargementillegal-christine-albanel-actualite-44869.html

Bhattacharjee, S., Gopal, R. D., and Sanders, G. L. (2003). Digital Music and Online Sharing: Software Piracy 2.0, Communications of the ACM, 46(7), pp. 107-111.

Blau, P. M. (1964). Exchange and Power in Social Life, John Wiley and Sons, New York, NY. Blackburn, D. (2004). Online Piracy and Recorded Music Sales, Working Paper, Department of Economics, Harvard University.

Business Software Alliance. (2012). 2011 Piracy Study,accessed May 4, 2014 http://portal.bsa.org/globalpiracy2011/.

Chaudhry, P., Cordell, V. and Zimmerman, A. (2005). Modeling Anti-counterfeiting Strategies in Response to Protecting Intellectual Property Rights in a Global Environment, Marketing Review, 5(1), pp. 59-72.

Chiou, J. S., Huang, C. Y. and Lee, H. H. (2005). The Antecedents of Music Piracy Attitudes and Intentions, Journal of Business Ethics, 57(2), pp. 161-174.

Chiu, S. P, and Chou, H. W. (2011). Investigating the User Behavior of Peer-to-Peer File Sharing Software, International Journal of Business and Management, 6 (9), 68-78.

Dimeglio, A. (2007). Telechargement Illegal: Quelsont les risqué ecourus? Le Journal du Net, accessed April 28, 2014, http://www.journaldunet.com/expert/9763/telechargement-illegalquels-sont-les-risques-encourus.shtml.

Fast Facts about AUI. (2014). Accessed May 5, 2014, http://www.aui.ma/en/about/general/quick-facts.html.

Gopal, R. D., Sanders, G. L., Bhattacharjee, S., Agrawal, M., and Wagner, S. C. (2004). A Behavior Model of Digital Music Piracy, Journal of Organizational Computing and Electronic Commerce, 14(2), pp. 89-105.

Hong, S. H. (2004). The Effect of Digital Technology on the Sales of Copyrighted Goods: Evidence from Napster, Working Paper, Department of Economics, Stanford University.

International Anti-Counterfeiting Coalition. (2005). Facts on Fakes, accessed April 25, 2014. www.iacc.org/ Facts.html.

Krasilovsky, M., Shemel, W., and Shemel, S. (2007). The Business of Music: The Definitive Guide to the Business and Legal Issues of the Music Industry. 10th. New York, USA: Crown Publishing Group.

Ki, E. J., Chang, B. H., and Khang, H. (2006). Exploring Influential Factors on Music Piracy across Countries, Journal of Communication, 56(2), pp. 406-426.

Kwong, T. C. H. and Lee, M. K. O. (2002). Behavioral Intention Model for the Exchange Mode Internet Music Piracy, Proceedings of the 35th Hawaii International Conference on System Science (CD-ROM), Hawaii, USA.

Lau, E. K. (2006). Factors Motivating People toward Pirated Software, Qualitative Market Research: An International Journal, 9(4): 404-419.

Liebowitz, S. (2004). Will MP3 downloads Annihilate the Record Industry? The Evidence so Far, Advances in the Study of Entrepreneurship, Innovation, and Economic Growth, V. 15, 2004, pp. 229-260.

IBT Journal of Business Studies (Formerly Journal of Management \& Social Sciences) 
Michael Ba, B. G. (2013). The Effects of Piracy and Counterfeiting on the International Economy, The Business Review, Cambridge 21(1), 33-43.

Michel, R. (2006). The Impact of Digital File Sharing on the Music Industry: An Empirical Analysis," Topics in Economic Analysis \& Policy 6(1), 1-22.

Moores, T. T. and Chang, J. C. J. (2006). Ethical Decision Making in Software Piracy: Initial Development and Test of a Four-Component Model, MIS Quarterly, 30(1), pp. 167-180.

Muncy, J. and Vitell, S. J. (1992). Consumer Ethics: An Investigation of the Ethical Beliefs of the Final Consumer, Journal of Business Research, 24(4), pp. 297-311.

Parameswaran, M., Susarla, A., and Whinston, A. B. (2001). P2P networking: An information sharing alternative. IEEE Comput. 34(7), 31-38.

Penn State Beaver. (2014). Accessed May 4, 2014, http://www.br.psu.edu/futurestudents.htm.

Peitz, M. and Waelbroeck, P. (2006). Why the Music Industry May Gain from Free Downloading - The Role of Sampling.International Journal of Industrial Organization, 24(5), 907-913.

Pikas, B., Pikas, A; Lymburner, C. (2011). The Future of the Music Industry, Journal of Marketing Development and Competitiveness, 5 (3), 139-149.

Sabbir, R., Haque, A., and Rahman, M. (2011). Purchasing Behavior for Pirated Products: A Structural Equation Modeling Approach on Bangladeshi Consumers, Journal of Management Research, 11(1), pp.48-58.

Spitz, D. and Hunter, S. (2003). The Social Construction of Napster, MIT Sloan Working Paper No. 4445-03, accessed April 28, 2014, http://ssrn.com/abstract=469283.

Stallman, R. (1995). Why Software should be Free, in D.G. Johnson and H. Nissenbaum (eds.), Ethics and Social Values, Prentice Hall, NJ, pp. 190-200.

Stone, B. (2009). Want to Copy iTunes Music? Go Ahead, Apple Says, New York Times 07 Jan 2009, accessed April 28, 2014, http://www.nytimes.com/2009/01/07/technology/companies/07apple.html?_r=0.

Tiwana, A. and Bush, A. (2000). Peer-to-Peer Valuation as a Mechanism for Reinforcing Active Learning in Virtual Communities: Actualizing Social Exchange Theory, Proceedings of the 33rd Hawaii International Conference on System Sciences, Hawaii, USA.

Vitell, S. J. (2003). Consumer Ethics Research: Review, Synthesis and Suggestions for the Future, Journal of Business Ethics, 43(1/2), pp. 33-47.

Vitell, S. J. and Muncy, J. (1992). Consumer Ethics: An Empirical Investigation of Factors Influencing Ethical Judgments of the Final Consumer, Journal of Business Ethics, 11(8), 585597.

Zentner, A. (2006). Measuring The Effect of Music Downloads on Music Purchases, The Journal of Law and Economics, 49(1), pp. 63-90. 